\title{
Inequality and Human Rights: Who Controls What, When, and How
}

\author{
TODD LANDMAN \\ University of Essex \\ Marco Larizza \\ University of Essex
}

\begin{abstract}
This article tests the empirical relationship between inequality and the protection of personal integrity rights using a cross-national time-series data set for 162 countries for the years 1980-2004. The data comprise measures of land inequality, income inequality, and a combined factor score for personal integrity rights protection, while the analysis controls for additional sets of explanatory variables related to development, political regimes, ethnic composition, and domestic conflict. The analysis shows robust support for the empirical relationship between income inequality and personal integrity rights abuse across the whole sample of countries as well as for distinct subsets, including non-communist countries and non-OECD countries. The hypothesized effect of land inequality is also born out by the data, although its effects are less substantial and less robust across different methods of estimation. Additional variables with explanatory weight include the level of income, democracy, ethnic fragmentation, domestic conflict, and population size. Sensitivity analysis suggests that the results are not due to reverse causation, misspecification or omitted variable bias. The analysis is discussed in the context of inequality and rights abuse in specific country cases and the policy implications of the results are considered in the conclusion.
\end{abstract}

\section{Introduction}

The U.S. State Department, Amnesty International, and Human Rights Watch annual reports on Brazil portray a remarkably consistent picture of the patterns of human rights abuse across its numerous states that include multiple extra-judicial killings; death squad activity linked to landowners and local police forces; extreme police violence, particularly in the favela (shantytown) areas of Rio De Janeiro and São Paulo; and persistent impunity for these abuses, which are largely explained by the incapacity of state judicial institutions to bring the perpetrators of these abuses

\footnotetext{
Authors' note: Equal authorship. We are grateful for theoretical and methodological discussions with and assistance from Thomas Plümper, Vera Troeger, and Hugh Ward, as well as assistance from Eric Tanenbaum in carrying out file conversions. Three anonymous reviewers also provided excellent feedback. Marco Larizza acknowledges financial assistance from the Economic and Social Research Council. Replication data and command files are available via the Dataverse. Network Project (http://dvn.iq.harvard.edu/dvn/dv/isq), the ISA data archive page (http://www.isanet.org/data_archive/), and the personal Web pages of Todd Landman (http://www.todd-landman. com).
} 
to justice. In its report for 2006, the U.S. State Department (2007) claims that death squads are now operating in 13 states across the country that are linked to police forces who target "suspected criminals and persons considered problematic by land owners or "undesirable.", The Pastoral Land Commission and Ombudsmen's Office of the Ministry of Agrarian Development report numerous killings and imprisonment of the rural landless and indigenous people as a result of the struggle for land (see also Human Rights Watch 2007). Amnesty International (2007) argues that there has been a "criminalization of poverty," where the urban poor are caught between criminal violence from drug gangs and heavy handed police tactics, leading to large numbers of extra-judicial killings, damage to property and infrastructure, the closure of businesses, and "curfew-like" conditions. It is clear from these various reports that the victims across these many years of documented abuse are predominantly the urban poor, rural landless people, and indigenous peoples (see also Adriance 1995; Arias 2006; Branford and Rocha 2002; Foweraker 1981). The broad commentary in the reports issued by these organizations posits a direct link between poverty, social exclusion, and access to land on the one hand, and human rights abuses on the other, where the state has thus far been incapable of providing protection for those rights guaranteed in the 1988 Brazilian National Constitution and the many international human rights treaties to which Brazil is a party. ${ }^{1}$

Human rights scholars and practitioners have long argued that the different categories of human rights (civil, political, economic, social, and cultural) are inalienable, indivisible, and interdependent. ${ }^{2}$ Such connections have often been merely declaratory in nature, and sit uncomfortably with social scientists engaged in research that examines such connections empirically (see Boyle 1995; Landman 2005a). The patterns of human rights abuse and the putative reasons for them in the Brazilian case outlined above, suggests that these declarations may well have some empirical support. But are the connections between land and income inequality and human rights violations restricted to the Brazilian case? Or is the relationship generalizable? Are countries with maldistributions of land and income more likely to have higher levels of human rights abuse? Answers to these questions have been partially provided in two different sets of literature. Studies on political violence have long examined the relationship between different forms of inequality (income and land) and general levels of political violence (e.g., Gurr 1968, 1970; Hibbs 1973; Sanders 1981; Sigelman and Simpson 1977; Weede 1986), where at best, the "repressiveness of the regime" (in our view, a proxy variable for human rights abuse) features as an intervening variable modeled to have an impact on political violence (e.g., Lichbach 1987; Muller 1985; Muller and Seligson 1987; Wang et al. 1993; Weede 1986). Studies on the cross-national variation in human rights protection operationalize human rights abuse as "stateled terror," but have rarely considered the relationship with different forms of inequality (e.g., Heinisch 1998; Henderson 1993; Landman 2005a,b; Mitchell and McCormick 1988; Poe and Tate 1994; Poe, Tate, and Keith 1999).

This article combines these two distinct sets of literature and tests the relationship suggested by the Brazilian case ${ }^{3}$ using a large cross-national time-series data

\footnotetext{
${ }^{1}$ As of December 2007, Brazil has ratified all the major international human rights treaties, with the exception of the First and Second Optional Protocol to the 1966 International Convention on Civil and Political Rights (see http://www.ohchr.org/english/countries/ratification/index.htm).

${ }^{2}$ One of the strongest expressions of this general idea of inter-relatedness of human rights can be found in the 1993 Vienna Declaration and Programme for Action (A/CONF.157 July 12, 1993).

${ }^{3}$ It is interesting to note that Muller and Seligson $(1987,436)$ claim that Brazil is a significant outlier (along with Panama and Gabon) in the relationship between income inequality and political violence, where it has remarkably (and in many ways paradoxically) low levels of political violence given its relatively high level of income inequality. In the current period, we see Brazil being a typical case in which high levels of inequality are associated with significant abuse of human rights and violence.
} 
set for 162 countries between 1980 and 2004. The data comprise measures of land inequality, income inequality, and a combined factor score for personal integrity rights protection, and additional sets of explanatory variables related to development (income, population size), political regimes (level of democracy and communism), ethnic composition, and domestic conflict. Using a method of estimation that takes into account the time-invariant and nearly time-invariant nature of many of the variables in the model (Plümper and Troeger 2007), the analysis shows robust support for the relationship across the whole sample of countries as well as for distinct subsets, including non-communist countries and non-OECD countries. The findings also show support for land inequality (albeit less robust), while the additional variables with explanatory weight include the level of income, democracy, ethnic fragmentation, domestic conflict, and population size. The article reviews briefly the extant global comparative literature on political violence and human rights, considers the micro and macro theoretical connections between inequality and human rights, describes the data and methods to estimate the model, presents analysis and findings, and then discusses their implications for an additional set of cases beyond Brazil in an effort to demonstrate the policy relevance of the findings.

\section{Inequality, Political Violence, and Human Rights}

The cross-national quantitative literature on political violence has invariably included some form of inequality as a key explanatory variable, which has been operationalized in terms of the distribution of income (some variant of the Gini co-efficient) or land (Gurr 1968; Gurr 1970; Hibbs 1973; Muller and Seligson 1987; Sanders 1981; Wang et al. 1993). The general finding of a positive relationship between high levels of inequality and political violence is often seen as mediated by the "repressiveness of the regime", or the propensity for the regime to violate human rights (e.g., Gurr 1970; Hibbs 1973; Lichbach 1987; Muller and Seligson 1987; Sanders 1981; Sigelman and Simpson 1977; Wang et al. 1993). Such a specification marginalizes the violation of human rights to a conditioning factor among many others and not as a substantive focus for explanation in and of itself. Moreover, the measure of political violence is normally so broad that it includes state and non-state violence, or "deaths from political violence" in the classic sense found in such sources as Taylor and Jodice (1983) or Banks (1994).

In contrast, this article is concerned with a particular form of violence: state violence against citizens. It is our view that this kind of violence constitutes a violation of fundamental human rights found in international human rights instruments, in particular the 1966 International Covenant on Civil and Political Rights (ICCPR), the First and Second Optional Protocols to the ICCPR, and the 1984 Convention Against Torture and other forms of Cruel, Inhuman, and Degrading Treatment. Human rights violations such as arbitrary detention, political imprisonment, disappearance, extra-judicial killing, torture, and other violations of civil and political rights carried out by state agents comprise our dependent variable. In this paper, we do not consider economic and social rights or "structural violations" of human rights, but focus on rights to personal integrity. Since the late 1970s (Claude 1976; McCamant 1981) human rights abuse (arguably personal integrity rights abuse) has featured as a dependent variable in its own right and not as some "mediating" condition that explains variation in some other dependent variable (with the exception of the work on foreign aid and human rights) (see Abouharb and Cingranelli 2007; Barratt 2004; Zanger 2000a). There has thus been a precedent set in political science that sees the variation in the protection of human rights as a substantive topic in need of empirical analysis separate from the studies on political violence (Landman 2002, 2005a). 
Since the first cross-national statistical analysis on human rights in late 1980s (Mitchell and McCormick 1988), there has been a proliferation of studies using increasingly large and complex data sets and an expanding list of independent variables (see Landman 2005a; Moore 2006). These variables most notably include the level, pace, and quality of economic development (e.g., Henderson 1991; Poe and Tate 1994; Poe, Tate, and Keith 1999); the level, timing, and quality of democratization (e.g., Davenport 1999; Davenport and Armstrong 2004; Bueno de Mesquita et al. 2005a; Zanger 2000b); involvement in internal and external conflict (Poe and Tate 1994; Poe, Tate, and Keith 1999); the size and growth of the population (Henderson 1993; Poe and Tate 1994; Poe, Tate, and Keith 1999); foreign direct investment and/or the presence of multinationals (Meyer 1996, 1998, 1999a,b; Smith, Bolyard, and Ippolito 1999); the level of global interdependence (Landman 2005b); and the growth and effectiveness of international human rights law (Hafner-Burton and Tsutsui 2005; Hathaway 2002; Keith 1999; Landman 2005b; Neumayer 2005).

Virtually absent from this cross-national literature, however, are studies that examine how acts of coercion and state violence toward citizens may be related to patterns of resource distribution. The findings to date for those few studies that do address this relationship remain mixed, especially for regional comparisons (see Duff and McCamant 1976; Henderson 1991; Muller 1985). The strongest and most consistent set of findings are found in Heinisch (1998, 353-61) who shows a negative impact for income inequality on both security rights and subsistence rights for a synchronic cross-sectional analysis of 117 countries. In the related literature on inequality and democracy, distribution of income, land, or "power resources" is specified as an independent variable that helps explain variation in the genesis and sustainability of democracy (e.g., Boix 2003; Boix and Stokes 2003; Midlarsky 1997, 1999; Vanhanen 1984, 1990, 1997, 2003).

Despite this relative lack of attention to resource distribution, there are both micro-theoretical and macro-theoretical reasons for why a relationship between inequality and human rights abuse ought to be observed. At a micro-level, there are several theoretical arguments linking resource distribution to coercion, all of which examine the link between assets, threats, and the propensity to employ violence against opponents. The work on the logic of political survival argues that in countries with a small winning coalition relative to the overall selectorate, there are a series of incentives for tolerating corruption, rent seeking, and the abuse of human rights (see Bueno de Mesquita et al. 2005b, 180-2) in ways that maintain loyalty among elites to the governing coalition. The desire of this relatively small coalition to stay in power through any means necessary suggests that such practices will be tolerated on a grander scale than in countries with a larger winning coalition relative to the overall selectorate. For Bueno de Mesquita et al. (2005b, 180), these practices are the "bread and butter of leaders who depend on a small coalition." In similar fashion, Poe's (2004) adoption of the Most and Starr (1989) model of government decision making, shows that the relative strength of a governing elite and its perception of threat are related to their use of repressive strategies and the violation of civil and political rights, where patterns of economic development represent a significant "entry point" for considering the relationship between the strength/threat ratio and abuse of human rights (Poe 2004, 26-8). Finally, Boix (2003) argues that in highly unequal societies, the redistributive demands of the worse-off citizens on the wealthy are particularly intense. As a result, the wealthy have a strong incentive (i.e., higher economic benefits) to resort to violence and repress popular demands for democratic institutions. Boix (2003) continues further that it is often the specificity of assets within the economy that may also be an underlying correlate of repression. Land represents the most important among the "fixed" assets that can be the 
target of expropriation and/or distributional demands from below and thus encourages repression.

At a macro-level, Cingranelli's work has focussed on inequality and repression (Cingranelli 1992; Abouharb and Cingranelli 2004, 2007). He argues that societies with inequitable distribution of income, power, and status among various ethnic, religious, and racial groups will tend to have more oppressive governments (Cingranelli 1992). This general claim is operationalized more fully in his more recent study on structural adjustment, where he argues that rapid economic liberalization leads to greater income and wealth disparities, more civil unrest and conflict, and less protection of civil and political rights (Abouharb and Cingranelli 2004, 2007, 6873; see also Brohman 1996, 173-97). Moreover, Abouharb and Cingranelli (2007, 69) link their critical macro-theory with other micro-theories, such as principalagent models (e.g., Mitchell 2004) in arguing that the reduction in the size of government that can occur on those countries that have undergone some form of structural adjustment means that fewer principals (e.g., government leaders) have the ability to constrain the discretion of agents (e.g., police and soldiers) in ways that will lead to less protection of civil and political rights.

These various arguments from the literature suggest that at a micro level, there are incentives for the "haves" in society to engage in rent-seeking behavior within governmental institutions, to maintain control of their resources, and to exclude access to those resources by the "have nots" in ways that use coercive means that undermine the protection of personal integrity rights (see Heinisch 1998; Henderson 1991, 125; Poe 2004). The distribution, accumulation, and defence of resource allocation at the micro level is historically driven and when aggregated to the macro level suggests that the means for maintaining these patterns of distribution may well include violations of civil liberties and personal integrity rights. Moreover, in the context of many lesser-developed countries, there can be state complicity and even collaboration in acts of coercion. We thus expect to find empirical support for a general relationship between inequality and human rights illustrated through our discussion of the Brazilian case.

We specify an empirical model to test our main hypothesis that countries with greater concentrations of income and/or land will be more likely to have worse records at protecting civil liberties and personal integrity rights (see Figure 1). In addition to this main relationship we specify a series of control variables that are drawn from the extant cross-national human rights and political violence literature (e.g., ethnic fragmentation, domestic conflict, population size, and economic development). In addition, our analysis models the relationship for a global sample of countries, all non-communist countries (or countries that had
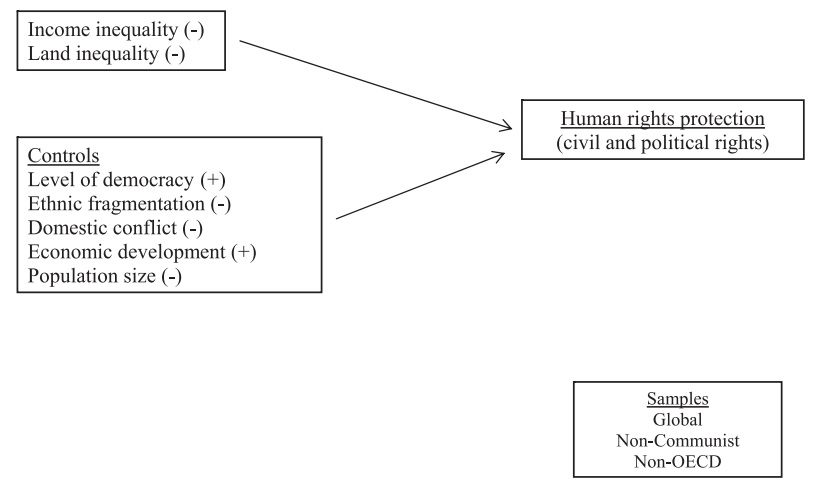

FIG. 1. Modeling Inequality and Human Rights 
not been previously governed by communist regimes) to control for nationalized assets and potential measurement errors in our land variable, and all non-OECD countries to test for the relationship without the presence of advanced industrial democracies. The data, methods, and further clarification on the expected direction of the effects for the independent variables are discussed in turn.

\section{Data and Methods}

The analysis uses a global data set on 162 countries between 1980 and 2004 (total $\mathrm{N}^{* \mathrm{~T}}=4050$ ). The process of case selection turned mainly to questions of data availability over time and was in no way a function of values on the dependent variable. Microstates with less than half a million inhabitants were eliminated, but the remaining cases provide meaningful geographical spread across different regions of the world. The data set is comprised of variables for personal integrity rights protection, income and land inequality, and the other variables outlined above.

\section{The Protection of Civil and Personal Integrity Rights}

The protection of civil and personal integrity rights is operationalized using five "standards-based" (Jabine and Claude 1992) human rights scales: (1) the Amnesty International version of the Political Terror Scale, (2) the U.S. State Department version of the Political Terror Scale, (3) the Cingranelli and Richards Index of Personal Integrity Rights (http://www.humanrightsdata.com), (4) the Freedom House civil liberties scale, and (5) Hathaway's (2002) scale of torture, which relies on source material from the U.S. State Department. A simple bi-variate Pearson's correlations matrix (see Table 1) indicates the existence of clusters of large and significant correlation coefficients between the human rights scales, suggesting that they may be measuring aspects of the same underlying dimension. The correlations for the torture scale are the lowest across the board, which reflects its more narrow focus on one form of human rights abuse (Hathaway 2002), but the values within the table range from .498 to .822 and are all at 99.9 percent levels of statistical significance. Given this degree of agreement among the different scales, we used principal components factor analysis to reduce the group of interrelated human rights variables. The analysis revealed five components, but only one has an eigenvalue greater than 1 (i.e., 3.295) and accounts for over 65 percent of the variance. ${ }^{4}$ The resulting factor loadings for this component (see Table 2) clearly show a strong relationship between each variable and the common underlying dimension they all measure. Moreover, the component represents a set of human rights violations that are consistent with Cingranelli and Richards (1999, 410) findings about the uni-dimensionality of their aggregate "personal integrity rights scale."

Once extracted, the human rights factor score has been inverted to make more intelligible its substantive meaning, where low values of the factor score correspond to a low protection of human rights (high violations) and high values correspond to a high protection of human rights (low violations). ${ }^{5}$ By definition, this variable is normally distributed, with a mean of 0 , a minimum value is -2.7 and a maximum value is 1.97 . The use of this component has several distinct

\footnotetext{
4 Given a different time coverage across the scales, we adopted the "substitute missing values with the mean" option to deal with missing cases, and ensure the widest coverage of the factor-score. This procedure is justified by the fact that missing cases are randomly distributed both across indicators and across countries (note also that for each country year between 1980 and 2004, at least two indicators were available).

${ }^{5}$ As alternative data-reduction strategy, we have standardized each of the five HR scales, and computed the unweighted average. The empirical analysis undertaken here is based on the HR factor score. However, the use of the "average" measure did not substantially alter the statistical findings.
} 
TABLE 1. Human Rights Scales Correlations

\begin{tabular}{|c|c|c|c|c|c|c|}
\hline Variable & & $P T S(A I)$ & PTS (SD) & $\begin{array}{l}\text { Torture } \\
\text { Scale }\end{array}$ & $\begin{array}{l}\text { Freedom } \\
\text { House Civil } \\
\text { Liberties }\end{array}$ & $\begin{array}{c}\text { CIRI } \\
\text { Physical } \\
\text { Integrity Index }\end{array}$ \\
\hline \multirow[t]{3}{*}{ PTS (AI) } & Pearson Correlation & 1 & $.820 * *$ & $.606^{* *}$ & $.512 * *$ & $.774 * *$ \\
\hline & Sig. (2-tailed) & & .000 & .000 & .000 & .000 \\
\hline & $N$ & 3362 & 3322 & 1936 & 3296 & 3058 \\
\hline \multirow[t]{3}{*}{ PTS (SD) } & Pearson Correlation & $.820 * *$ & 1 & $.683^{* *}$ & $.589 * *$ & $.822 * *$ \\
\hline & Sig. (2-tailed) & .000 & & .000 & .000 & .000 \\
\hline & $N$ & 3322 & 3647 & 2112 & 3576 & 3318 \\
\hline \multirow[t]{3}{*}{ Torture Scale } & Pearson Correlation & $.606^{* *}$ & $.683 * *$ & 1 & $.498^{* *}$ & $.685^{* *}$ \\
\hline & Sig. (2-tailed) & .000 & .000 & & .000 & .000 \\
\hline & $N$ & 1936 & 2112 & 2198 & 2138 & 2059 \\
\hline \multirow{3}{*}{$\begin{array}{l}\text { Freedom House } \\
\text { Civil Liberties }\end{array}$} & Pearson Correlation & $.512 * *$ & $.589 * *$ & $.498^{* *}$ & 1 & $.591 * *$ \\
\hline & Sig. (2-tailed) & .000 & .000 & .000 & & .000 \\
\hline & $N$ & 3296 & 3576 & 2138 & 3751 & 3378 \\
\hline \multirow{3}{*}{$\begin{array}{l}\text { CIRI Physical } \\
\text { Integrity Index }\end{array}$} & Pearson Correlation & $.774 * *$ & $.822 * *$ & $.685^{* *}$ & $.591 * *$ & 1 \\
\hline & Sig. (2-tailed) & .000 & .000 & .000 & .000 & \\
\hline & $N$ & 3058 & 3318 & 2059 & 3378 & 3445 \\
\hline
\end{tabular}

**Correlation is significant at the .01 level (2-tailed).

TABLE 2. Component Loadings

\begin{tabular}{lc}
\hline & Component 1 \\
\hline PTS (AI) & .845 \\
PTS (SD) & .909 \\
Torture Scale & .684 \\
Freedom House Civil Liberties & .720 \\
CIRI Physical Integrity Index & .877 \\
\hline
\end{tabular}

Extraction Method: principal component analysis.

advantages. It simplifies the presentation of the empirical findings, reduces the need for tests of robustness that substitute various specifications of the dependent variable, ${ }^{6}$ and avoids using ordered probit estimation techniques that are less easy to interpret than more standard regression estimators.

\section{Inequality}

For income inequality, we use a new measure based on the "inequality project" (UTIP) developed by James K. Galbraith and Hyunsub Kum at the University of Texas, Austin. In an effort to overcome the well-known deficiencies of the Deininger and Squire (1996) data set on income inequality (i.e., sparse coverage, problematic measurements, and the combination of diverse data types into a single data set), Galbraith and Kum use the UTIP-UNIDO measures of manufacturing pay inequality as an instrument to create a new panel data set of estimated household income inequality (EHII), which covers a large panel of countries from 1963 through 1999, for nearly 3,200 country-years. This new dataset provides comparable and consistent measurements across space and through time, thus being a more valid proxy of income inequality than the Deininger

\footnotetext{
${ }^{6}$ We estimated the models that appear in this article using both the extracted factor score and the separate measures for civil and personal integrity rights, but only report those for the factor score since the results did not differ significantly (see the Analysis section).
} 
and Squire data usually employed by cross-national empirical studies (Galbraith and Kum 2004). For the present inquiry, a linear interpolation of the original EHII variable has been computed for each country-series to increase the number of observations. ${ }^{7}$

For land inequality, we use a measure that is expressed as the area of family farms as a percentage of the total area of land holdings (Vanhanen 1997). The reasoning behind this measure is that the higher the percentage of family farms, the more widely economic power resources based on ownership patterns of agricultural land are distributed (Vanhanen 1997; 47). Family farms are defined as "holdings that are mainly cultivated by the holder family and that are owned by the cultivator family or held in ownerlike possession" (Vanhanen 1997, 49). The data on landownership were mainly derived from the FAO World Censuses of Agriculture (from the 1960s to the 1980s) and Vananhen's own estimations for the 1990s. As with our income inequality data, these data were interpolated to fill in missing time points for those countries where two or more time points of data were made available. ${ }^{8}$ To make this variable equivalent to income inequality in terms of its measurement of land inequality, it has been inverted by subtracting the original percentage value from 100 such that a low score means a more favorable distribution of land.

Other researchers have used different indicators to measure land inequality. The most common alternative would have been the Gini index of land concentration (Muller and Seligson 1987; Russett et al. 1964). This type of index calculates "the difference between an 'ideal' cumulative distribution of land (where all farms are the same size) and the actual distribution" (Russett et al. 1964, 237-8). We prefer our measure to the Gini index for three reasons. First, without controlling for the ownership of land, the Gini index does not adequately capture the relative distribution of economic resources among those who cultivate the land, and is thus insensitive to the kind of asset inequality we believe is most likely to be related to human rights abuses. Second, Brockett's (1992, 172) empirical analysis clearly demonstrates that land distribution data based on the Gini index tend to underestimate land maldistribution in countries characterized by the prevalence of landlessness among peasants. Third, the necessary data on the number and size of land holdings (required to compute the Gini Index) are not available for most of the developing countries, thereby seriously compromising the global perspective of our study (Vanhanen 1997, 50). The alternative measure of land inequality adopted by Prosterman and Riedinger (1987) would be more in line with our purposes, but again, of limited practical utility given its small coverage. ${ }^{9}$

\section{Democracy}

For the level of democracy, we use the Polity IV 20-point combined democracy score (DEMOC-AUTOC), which ranges from -10 to +10 . The variable POLITYIV2-which is also used here-incorporates the authors recommendations for transforming Polity "standardized authority codes" (i.e., -66, -77, and -88 for interruption, interregnum, or transition) to scaled POLITY scores

\footnotetext{
${ }^{7}$ Whenever missing, the first and the last observation year for each country series have been substituted with the mean. A linear interpolation has then been computed.

${ }^{8}$ The original decennial data on family farms are given in Vanhanen (1997), Appendix 5. These raw data provide a total of 384 observations in our sample, from which we performed a linear interpolation to fill in the missing values.

${ }^{9}$ Prosterman and Riedinger (1987, 10-11, 25) hypothesize that landlessness, rather than inequality in the distribution of land, is the most important cause of deeply felt grievances among peasants. They define landlessness as the lack of "ownership or ownership-like rights" among "those who cultivate the land" and measure it with the percentage of landless peasants out in the entire population.
} 
so that the variable may be used consistently in time-series analyses without losing crucial information by treating the "standardized authority scores" as missing values. Given the large number of consistent findings for the positive relationship between democracy and human rights (see Bueno de Mesquita et al. 2005a; Davenport 1999; Davenport and Armstrong 2004; Poe and Tate 1994; Poe, Tate, and Keith 1999; Zanger 2000b), we also expect a positive relationship for this variable.

\section{Ethnic Fractionalization}

The level of ethnolinguistic fractionalization is measured using data from Alesina et al. (2003). The fractionalization index is computed by using the Herfindahl index of ethnolinguistic group shares, which represents an improvement over existing measures (e.g., La Porta et al. 1999) by compiling a separate variable for ethnic fragmentation. Their main goal is "to clearly distinguish between ethnic, religious, and linguistic heterogeneity," where "[a]lternative indicators tend to lump together ethnic and linguistic differences as part of an 'ethnolinguistic' fractionalization variable" (Alesina et al. 2003, 158). Since their measure is more disaggregated it has the potential for better differentiation between the dimensions of fractionalization, even though some of those dimensions can be overlapping. ${ }^{10}$ This variable is included since several studies on ethnic conflicts have shown that multi-cultural societies are especially prone to political instability, domestic violence, and eventually state terror, as authorities are more likely to resort to coercive means to deal with ethnically based mobilizations and acts of political dissent (Rabushka and Shepsle 1972; Walker and Poe 2002). In our preliminary analysis of this variable, we discovered that its relationship with the protection of human rights is curvilinear such that up to a point increasing fractionalization is negatively related to the protection of human rights, but then declines as the level of fractionalization increases. In other words, countries with a small number of distinct lines of ethnic cleavage tend to have worse protection of human rights, while those with a large plurality of groups tend to have better protection of human rights. We thus specify our model to include a squared term of this variable to take into account this particular functional form.

\section{Domestic Conflict}

As in the research on human rights and political violence, we include a variable for internal domestic conflict, which is specified as an independent variable alongside the other variables in our model. We do not use the simple dummy variable for civil war from the Correlates of War project (Singer and Small 1994) as in much of extant work on human rights, nor do we use events-based measures of the kind coded from single and multiple news sources found in the literature on political violence. The civil war dummy is still a fairly crude variable that tends to absorb quite a lot of the explanatory space in most human rights literature (see Poe and Tate 1994) and the events-based measures have proved to be fairly insecure for the kind of cross-national and time-series comparisons conducted here on grounds of validity and reliability. We thus employ the International Country Risk Guide (ICRG) measure of internal conflict, which is an aggregate 12-point scale that comprises the overall risk levels for civil war and threat of a military coup, terrorism and political violence, and general levels of

\footnotetext{
${ }^{10}$ As they acknowledge, "It would be wrong to interpret our ethnicity variable as reflecting racial characteristics alone, but it does reflect these characteristics to a greater extent than our language variable" (Alesina et al. 2003, 4-6).
} 
civil disorder. We feel that this measure is superior in some respects since it provides greater variance than the civil war dummy and perhaps greater validity than the event-based measures of conflict to date. We expect this variable to have a negative relationship with the protection of human rights, which is consistent with the findings in both literatures.

\section{Other Control Variables}

The level of economic development is measured through the natural log of the value of real per capita income (GDP, constant 2,000 US \$), and is taken from the World Bank Development Indicators. We expect this variable to have a positive relationship with the protection of human rights.

Total population size is based on de facto definition of population, which counts all residents regardless of legal status or citizenship-except for refugees not permanently settled in the country of asylum, which are generally considered part of the population of their country of origin. The variable is taken from the World Bank and has been logged to correct for skewed distribution. We expect this variable to have a negative relationship with the protection of human rights, since more populous countries tend to have greater difficulty in protecting personal integrity rights. ${ }^{11}$

OECD membership is a dummy variable indicating whether or not a country is an OECD member in a given year. We use this variable as a proxy indicator of the "developed" vs. "developing" countries in the world.

Communist country is a dummy variable for those countries that are currently, or have been, governed by a Communist regime. These countries and the years within our data set include Albania (1980-1989), Armenia (1980-1991), Azerbaijan (1980-1991), Belarus (1980-1991), Bulgaria (1980-1989), China, Cuba, Estonia (1980-1991), Georgia (1980-1991), Hungary (1980-1989), Kazakhstan (1980-1991), Kyrgyzstan (1980-1991), Lao People Republic, Latvia (1980-1991), Lithuania (1980-1991), Mongolia (1980-1991), Poland (1980-1989), Romania (1980-1989), Tajikistan (1980-1991), Turkmenistan (1980-1991), Ukraine (1980-1991), Uzbekistan (1980-1991), Yugoslavia (1980-1991), Czechoslovakia (1980-1989), North Korea; USSR (1980-1991). As will become clear in the subsequent analysis, communist regimes have nationalized land holdings and operated command economies both of which have an impact on our measures of land and income inequality. We thus check the robustness of the model across the entire sample of countries as well as subsets that do not include these countries.

\section{Methods of Estimation}

Our data set follows by now what has become a standard construction of a matrix of cross-section and time-series units, where variation in the variables and the number of observations are maximized across time and space. Such data sets do, however present a number of problems for estimating parameters using standard regression techniques. First, the error terms tend to be correlated from one time period to the other (serial correlation). Second, the error terms tend to be heteroskedastic, which means that they tend to have different variances across units (Beck and Katz 1995, 637-8; Stimson 1985, 19). To control for serial correlation, we model the dynamics of our data by introducing a Prais-Winsten (first

\footnotetext{
11 Beside theoretical reasons, the inclusion of population size variable is also justified according to methodological concerns. Since the sources used to develop our dependent variable (human rights factor score) are based on event count information, which do not control for population size itself, differences in population size must be accounted for in any models using these data to avoid misspecification.
} 
order) autoregressive transformation. ${ }^{12}$ To control for heteroskedasticity, we adopt a variation of White's (1980) estimator of robust standard errors that adjusts for clustering across countries. ${ }^{13}$

In addition to the standard problems mentioned above, our data set has the additional problems of unit-specific effects ${ }^{14}$ associated with time invariant or nearly time invariant variables (Plümper and Troeger 2007). When unit effects are present, but not explicitly modeled, their presence is picked up in the error term, and consequently, if these unit effects are then correlated with one or more explanatory variables, the error term too will be correlated with the explanatory variables, and simple OLS would produce biased coefficient estimates. Plümper and Troeger (2007) have devised a three-stage regression technique known as "fixed effects vector decomposition" (FEVD) that "decomposes" the explained and unexplained elements of the fixed effects and produces final estimates that take into account the particular qualities of time invariant or nearly time invariant variables.

In order to identify the time invariant and nearly time invariant variables in our data set we compared the "between-unit" variation to the "within-unit" variation (see Table A1). We then used the rule of thumb that those variables for which "between-unit variation" is 2.5 times larger than "within-unit variation" we specify as invariant or nearly invariant. Those variables for which this is the case include income and land inequality, per capita GDP, population size, and both forms of the ethnic fractionalization variable. We thus adopt the fixed effect vector decomposition method of estimation and specify these variables in the FEVD procedure as invariant. By doing so, we successfully combine the benefits of an increased number of observations with the ability to control for unobservable country-specific differences, eliminating much of the omitted variable bias of cross-section data.

\section{Analysis and Results}

In the first section of the article, we advanced the proposition that there is an empirical relationship between inequality and personal integrity rights. The bivariate correlation co-efficients for the whole sample over time lend support to this general interpretation where the relationship for income inequality is stronger than for land inequality $(r=-.38 ; p<.001$ and $r=-.22 ; p<.001$, respectively). The multiple regression analysis estimates four different models that include the main variables identified in the general model depicted in Figure 1, but controls for different groups of countries. The dependent variable is the human rights factor score, which varies from low protection to high protection of civil liberties and personal integrity rights. The independent variables are income and land inequality, the level of democracy, the two ethnic fractionalization variables, domestic conflict, population size, and economic development. All

\footnotetext{
12 This solution departs from the standard method suggested by Beck and Katz (1995), advocating the inclusion of a lagged dependent variable in the right side of the equation, but often the inclusion of a lagged dependent variable tends to produce misleading results as it "may absorb large parts of the trend without actually explaining it" (Plümper, Troeger, and Manow 2005, 335,).

${ }^{13}$ With the clustering option, we have assumed heteroskedasticity across units but not within units. This option is available in the FEVD estimator, and is similar to the Beck and Katz (1995) panel-corrected standard errors (PCSE) method, which assumes that the variance of the error term is heteroskedastic across panels and homoskedastic within panels.

${ }^{14}$ To detect the presence of unit-effects correlated with the regressors, we have run a Hausman test for unit heterogeneity (Hausman 1978) and compared the estimates produced by a FE (fixed effects model) with the estimates produces by a RE (random effects model). For all our four model specifications, the Hausman test is statistically significant, indicating that we can reject the null hypothesis of strict exogeneity between the regressors and the error term. We can therefore conclude that the presence of unit-effects is correlated with the regressors, which are not adequately controlled for by simple OLS.
} 
TABLE 3. Non-instrumented Models

\begin{tabular}{|c|c|c|c|c|}
\hline & Model 1 & $\begin{array}{c}\text { Model } 2 \\
\text { Non-communist }\end{array}$ & $\begin{array}{l}\text { Model } 3 \\
\text { Non-OECD }\end{array}$ & $\begin{array}{c}\text { Model } 4 \\
\text { Non-communist } \\
\text { Non-OECD }\end{array}$ \\
\hline Constant & $\begin{array}{l}4.255^{* * *} \\
(0.044)\end{array}$ & $\begin{array}{l}4.449 * * * \\
(0.044)\end{array}$ & $\begin{array}{l}5.138^{* * *} \\
(0.064)\end{array}$ & $\begin{array}{l}5.286 * * * \\
(0.065)\end{array}$ \\
\hline Income inequality $\mathrm{t}_{\mathrm{f}} 1$ & $\begin{array}{l}-\mathbf{0 . 0 3 7 * * * *} \\
(0.004)\end{array}$ & $\begin{array}{l}-\mathbf{0 . 0 4 1} * * * \\
(0.004)\end{array}$ & $\begin{array}{l}-\mathbf{0 . 0 2 1} * * * \\
(0.004)\end{array}$ & $\begin{array}{l}-\mathbf{0 . 0 2 1} * * * * \\
(0.005)\end{array}$ \\
\hline Land inequality $\mathrm{t}_{\mathrm{t}} 1$ & $\begin{array}{l}-0.006 * * * \\
(0.002)\end{array}$ & $\begin{array}{l}-0.005^{* *} \\
(0.002)\end{array}$ & $\begin{array}{l}-\mathbf{0 . 0 0 4} * * \\
(0.002)\end{array}$ & $\begin{array}{c}-\mathbf{0 . 0 0 4} * \\
(0.002)\end{array}$ \\
\hline \multicolumn{5}{|l|}{ Controls } \\
\hline Level of Democracy $t_{t-1}$ & $\begin{array}{l}0.024 * * * \\
(0.000)\end{array}$ & $\begin{array}{l}0.021 * * * \\
(0.000)\end{array}$ & $\begin{array}{l}0.025^{* * *} \\
(0.000)\end{array}$ & $\begin{array}{l}0.021 * * * \\
(0.000)\end{array}$ \\
\hline Ethnic fragmentation $_{t-1}$ & $\begin{array}{l}-1.388^{* * * *} \\
(0.013)\end{array}$ & $\begin{array}{l}-1.316^{* * * *} \\
(0.013)\end{array}$ & $\begin{array}{l}-0.330 * * * \\
(0.022)\end{array}$ & $\begin{array}{l}-0.128 * * * \\
(0.024)\end{array}$ \\
\hline $\begin{array}{l}\text { Ethnic fragmentation } \\
\text { squared }_{t-1}\end{array}$ & $\begin{array}{l}1.706^{* * *} \\
(0.015)\end{array}$ & $\begin{array}{l}1.606 * * * \\
(0.016)\end{array}$ & $\begin{array}{l}0.293^{* * *} \\
(0.031)\end{array}$ & $\begin{array}{l}0.067 * * \\
(0.032)\end{array}$ \\
\hline Domestic conflict $_{t-1}$ & $\begin{array}{c}-0.023 * * * \\
(0.002)\end{array}$ & $\begin{array}{l}-0.026^{* * *} \\
(0.003)\end{array}$ & $\begin{array}{l}-0.026^{* * *} \\
(0.005)\end{array}$ & $\begin{array}{l}-0.028 * * * \\
(0.005)\end{array}$ \\
\hline Population size $_{\mathrm{t}-1}$ & $\begin{array}{l}-0.243^{* * *} \\
(0.001)\end{array}$ & $\begin{array}{l}-0.244^{* * * *} \\
(0.001)\end{array}$ & $\begin{array}{l}-0.289 * * * \\
(0.001)\end{array}$ & $\begin{array}{l}-0.298 * * * \\
(0.001)\end{array}$ \\
\hline Economic Development $t_{t-1}$ & $\begin{array}{l}0.244^{* * *} \\
(0.000)\end{array}$ & $\begin{array}{l}0.241 * * * \\
(0.000)\end{array}$ & $\begin{array}{l}0.092^{* * * *} \\
(0.000)\end{array}$ & $\begin{array}{l}0.087 * * * \\
(0.000)\end{array}$ \\
\hline Eta & $\begin{array}{l}0.933 * * * \\
(0.001)\end{array}$ & $\begin{array}{l}0.942^{* * * *} \\
(0.001)\end{array}$ & $\begin{array}{l}0.929 * * * \\
(0.001)\end{array}$ & $\begin{array}{l}0.942 * * * \\
(0.001)\end{array}$ \\
\hline D-W (transformed) & 1.92 & 1.94 & 1.90 & 1.91 \\
\hline Adjusted $R^{2}$ & .82 & .82 & .71 & .71 \\
\hline$N$ & 1678 & 1637 & 1277 & 1236 \\
\hline
\end{tabular}

Dependent Variable: HR factor score. Unstandardized beta coefficients reported with robust standard errors in parentheses (adjusted for clustering by country). $* p<.10, * * p<.05, * * * p<.001$.

Method of Estimation: fixed effects vector decomposition. This includes a variable (labeled eta), representing the unexplained part of the estimated unit effects, or the residual from regressing the unit-specific effects on the observed time-invariant and rarely changing variables. It approaches 1 by construction (Plümper and Troeger 2007, $5-6)$.

the variables have been lagged one-year to control for simultaneity bias. All of the models were estimated using the fixed effects vector decomposition (FEVD) method of estimation discussed above. ${ }^{15}$ Table 3 reports the unstandardized coefficients with the robust standard errors in parentheses. ${ }^{16}$

Reading the column for the first model in Table 3 shows that both income and land inequality have negative and significant effects on human rights protection, while the magnitude of the effect is greater for income inequality than land inequality. These results are robust and largely unaffected by the subsets of countries included in the sample: both our variables remain statistically significant in the global sample of 162 countries (Model 1) as well as in the models that exclude the communist countries (Model 2), for the sample of non-OECD countries (Model 3) as well as the sample that excludes both the communist and the OECD countries (Model 4). Democracy has a positive and significant effect on human rights protection (i.e., is associated with lower levels of violation). Economic development has a positive and significant effect on protection, while

\footnotetext{
${ }^{15}$ The xtfevd ado file and help file (for Stata 7.0.-9.x) is available at Thomas Plümper's Web page http:// www.polsci.org/pluemper/xtfevd.htm.

${ }^{16}$ The Durbin-Watson statistic after the Prais-Winsten transformation shows that no further correlation in the error terms is suspected.
} 
domestic conflict and the size of the population both have negative and significant effects (i.e., are associated with higher levels of human rights violations). These findings for this set of variables are entirely consistent with findings in the extant cross-national literature on human rights. As outlined above, our initial modeling (not reported here) of ethnic and religious fragmentation revealed that ethnic fragmentation exhibits a "u" relationship with human rights protection (hence the inclusion of the original variable for ethnic fractionalization and its squared version). In other words, human rights violations increase with an increase in ethnic fragmentation, but once such fragmentation reaches a certain point, human rights violations begin to decrease as inter-ethnic fractionalization becomes more dispersed.

Depending on the size of the sample, the marginal effects of our inequality variables vary, being quite substantial both in absolute terms and relative to the other factors considered to be powerful predictors of cross-country variations in human rights protection. Our results show that one standard deviation decrease in the level of income inequality would produce a 26 percent increase in the level of personal integrity rights protection, whereas one standard deviation decrease in the level of land inequality would produce a 13 percent increase in the personal integrity rights protection. The stronger findings for income inequality ${ }^{17}$ suggest that income distribution may well have more of a consistent impact on the protection of human rights than land distribution. This might confirm-albeit indirectly-the conclusions of previous studies about the lower level of political mobilization of rural workers and landless peasants (Collier and Hoeffler 2004): the rising opportunity costs of violence associated with rural environment might in turn require less aggressive anti-human rights policy. On the other hand, it might well be that in this instance income inequality has been measured better than land inequality. Indeed, as Seligson $(1997,282)$ pointed out, misspecification errors might affect the major source upon which our measure of land inequality is estimated: "census data can have systematic bias, under-representing the largest farms and over-representing the smallest farms." If so, the estimates used by Vanhanen might artificially produce more egalitarian land tenure conditions, therefore decreasing the magnitude of the effect of land inequality variable in our models. ${ }^{18}$ It is also telling that the magnitude and significance of the coefficients for the inequality measures are roughly similar to those for our other explanatory variables, suggesting that we have captured significant additional explanatory factors that, to date, have remained relatively under-examined.

\section{Some Potential Problems: Endogeneity and Misspecification}

Our main finding is that the existence of asset inequality (at least insofar as land is concerned), and income inequality help explain the cross-country variation in personal integrity rights violations. But are these results clouded by an endogeneity problem? Might the abuse of personal integrity rights be the cause of higher inequalities, instead of-or in addition to-the reverse? If this is the case, we might not have correctly specified the direction of the relationship in our empirical models correctly. Indeed, several effects might lead to a reverse-or at least

\footnotetext{
${ }^{17}$ We re-estimated the models using a different strategy for missing-data (i.e., substituted all missing data with the country average rather than estimating linear interpolation) and the results were almost identical.

${ }^{18}$ Moreover, Vanhanen's measure of land inequality presents some limitations for the subsample of socialist and former socialist countries, since the agricultural surveys of the FAO usually count both private small-holders and communal holdings as individual farm holdings, thus artificially over-representing the inequality of "access" to land in socialist and former socialist countries (Frankema 2006,7). The lack of statistical data for socialist countries forced Vanhanen to estimate the share of private farms and use it as a proxy to indicate the percentage of family farms. We dealt with this potential measurement error by excluding the communist countries from our sample for alternative model estimations.
} 
simultaneous-relationship. For example, more rights abuses might be related to greater income inequality, if economic elites use violence to control the workers and successfully repress collective forms of protests for better wages and access to land. According to this perspective, human rights violations can be considered as the starting point, which covers political decisions to shift assets and resources to the economically privileged. Indeed, the historical experience of land-abundant countries in Latin America and Sub-Saharan Africa shows that the landowning elites tend to develop coercive labor market institutions (in the form of slavery or modern forms of peonage) and forcefully restrict access to land to underprivileged groups in order to protect their economic interests within the land market (Domar 1970; Engerman and Sokoloff 2005).

To rule out these potential sources of a two-way relationship and mitigate bias of the regression estimates in our models, ${ }^{19}$ we specified a two-stage least-squares (2SLS) estimator, re-running the original models with multiple instrumental variables. ${ }^{20}$ The instrumental variables were selected drawing on a vast array of studies analyzing the determinants of income and land inequality. ${ }^{21}$ They include: (1) one dummy variable capturing the special conditions associated with Iberian colonization, ${ }^{22}$ which are expected to have interfered in the distribution of land and income; (2) one variable measuring the percentage share of Catholics out of the total population, to capture the impact of the Catholic Church on the distribution of land; ${ }^{23}$ (3) two continuous variables on "fuel" and "ores and metals" exports as a percentage of total merchandise exports, ${ }^{24}$ capturing the impact on inequality of particular resource sectors which are location-specific and may be confined to secured enclaves; ${ }^{25}$ and (4) one variable measuring agriculture's share of GDP, as a proxy for capturing the human capital formation and the availability of skilled workers within the economy. ${ }^{26}$

${ }^{19}$ To detect potential endogeneity bias, we have performed further statistical diagnostics by computing a Durbin-Wu-Hausman (DWH) augmented test (Davidson and Mackinnon 1993). Regardless of the variables used as instruments, the regression results consistently indicated that we could reject the null hypothesis of strict exogeneity for both our explanatory variables (land inequality and income inequality).

${ }^{20}$ More precisely, we have specified an instrumental variable estimator on stage 2 of our FEVD estimator.

${ }^{21}$ Here, the difficulty is to find outside data (or instruments) that are uncorrelated with the unit specific effects and at the same time partially correlated with the endogenous explanatory variables. Clearly, the fist condition can never be checked and must therefore be maintained as assumption. However, following Wooldridge (2003, 473), we verified the second condition by a simple regression between the selected instrumental variables (IVs) and each of the two endogenous explanatory variables. Regression coefficients were always significant and in the expected direction.

${ }^{22}$ This variable has a value of 1 for each former Iberian colony, 0 otherwise. Previous studies have identified specific colonial institutions among the historical determinants of land inequality. For example, Engerman and Sokoloff (1997) point out that land inequalities reflect the specific paths of colonization followed in Iberian colonies, where the deliberate expropriation of land and the exploitation of forced labor were two complementary aspects of the same "extractive" colonial policy. Likewise, Frankema (2006) argues that Iberian colonial institutions such as the encomienda and the latifundia played a crucial role in shaping long-term patterns of unequal distribution of land and income.

${ }^{23}$ The variable is taken from La Porta et al. (1999). Previous studies have argued that countries in which the Catholic Church has become a powerful institution inherited high levels of land inequality. According to Van Oss (2003), the Catholic Church established specific inheritance laws in order to enlarge its landed estates and traded salvation in return for generous gifts from the faithful Christians. As result of this process, the extent of the Church's estates reached impressive size, shaping long-term patterns of land inequality in Spanish America. See also Lal (1998) and Frankema (2006) for insightful analysis of the long-term impact of the Catholic culture on patterns of socio-economic development.

24 "Fuel" comprises the commodities in section 3 of the Standard International Trade Classification (SICT), including mineral fuels, lubricants, and related materials. Ores and metals comprise the commodities in SITC section 27 (crude fertilizer, non-oil minerals), section 28 (metalliferous, ores, and scrap), and 68 (non-ferrous metals). The data for both variables are from the World Bank's World Development Indicators.

${ }^{25}$ Given the nature of the extraction process for these commodities, countries that are more dependent on these exports will have greater concentrations of economic activity in resources that are not widely distributed.

${ }^{26}$ The data for this variable are from the World Bank's World Development Indicators. We included this variable as an additional instrument following Bourguignon and Morrisson (1998), who have shown that human resource endowments or the share of skilled workers in total labor force exert significant income equalizing effects. 
TABLE 4. Instrumented Models

\begin{tabular}{|c|c|c|c|c|}
\hline & Model 1 & $\begin{array}{c}\text { Model } 2 \\
\text { Non-communist }\end{array}$ & $\begin{array}{c}\text { Model } 3 \\
\text { Non-OECD }\end{array}$ & $\begin{array}{c}\text { Model } 4 \\
\text { Non-communist } \\
\text { Non-OECD }\end{array}$ \\
\hline Constant & $\begin{array}{l}12.927 * * * \\
(0.008)\end{array}$ & $\begin{array}{l}12.578^{* * * *} \\
(0.009)\end{array}$ & $\begin{array}{l}10.951 * * * \\
(0.009)\end{array}$ & $\begin{array}{l}9.704^{* * *} \\
(0.012)\end{array}$ \\
\hline Income inequality $\mathrm{t}_{\mathrm{t}} \mathrm{1}$ & $\begin{array}{l}-0.158 * * * \\
(0.001)\end{array}$ & $\begin{array}{l}-\mathbf{0 . 1 5 7 * * *} \\
(0.001)\end{array}$ & $\begin{array}{l}-\mathbf{0 . 1 0 4 * * *} \\
(0.001)\end{array}$ & $\begin{array}{l}-\mathbf{0 . 0 8 7 * * * *} \\
(0.001)\end{array}$ \\
\hline Land inequality -1 & $\begin{array}{l}-0.0001 * * * \\
(0.001)\end{array}$ & $\begin{array}{l}-0.0001 * * * \\
(0.001)\end{array}$ & $\begin{array}{l}-0.001 * * * \\
(0.001)\end{array}$ & $\begin{array}{l}-0.002 * * * \\
(0.001)\end{array}$ \\
\hline \multicolumn{5}{|l|}{ Controls } \\
\hline Level of Democracy $y_{t-1}$ & $\begin{array}{l}0.024 * * * \\
(0.001)\end{array}$ & $\begin{array}{l}0.021 * * * \\
(0.001)\end{array}$ & $\begin{array}{l}0.025 * * * \\
(0.001)\end{array}$ & $\begin{array}{l}0.021^{* * *} \\
(0.001)\end{array}$ \\
\hline Ethnic fragmentation $_{t-1}$ & $\begin{array}{l}-0.839 * * * \\
(0.004)\end{array}$ & $\begin{array}{l}-0.859^{* * *} \\
(0.004)\end{array}$ & $\begin{array}{l}-1.594 * * * \\
(0.006)\end{array}$ & $\begin{array}{l}-1.587 * * * \\
(0.006)\end{array}$ \\
\hline Ethnic fragmentation squared $t_{t-1}$ & $\begin{array}{l}2.035^{* * *} \\
(0.004)\end{array}$ & $\begin{array}{l}1.841^{* * *} \\
(0.004)\end{array}$ & $\begin{array}{l}2.286 * * * \\
(0.006)\end{array}$ & $\begin{array}{l}2.050^{* * *} \\
(0.007)\end{array}$ \\
\hline Domestic conflict $t_{t-1}$ & $\begin{array}{c}-0.023^{* * *} \\
(0.001)\end{array}$ & $\begin{array}{l}-0.026^{* * *} \\
(0.001)\end{array}$ & $\begin{array}{l}-0.026^{* * * *} \\
(0.001)\end{array}$ & $\begin{array}{l}-0.028^{* * * *} \\
(0.001)\end{array}$ \\
\hline Population size $\mathrm{t}_{\mathrm{-}} 1$ & $\begin{array}{l}-0.383 * * * \\
(0.001)\end{array}$ & $\begin{array}{l}-0.349 * * * \\
(0.004)\end{array}$ & $\begin{array}{l}-0.392 * * * \\
(0.002)\end{array}$ & $\begin{array}{l}-0.361 * * * \\
(0.002)\end{array}$ \\
\hline Economic Development $_{\mathrm{t}-1}$ & $\begin{array}{l}0.041 * * * \\
(0.001)\end{array}$ & $\begin{array}{l}0.023^{* * * *} \\
(0.001)\end{array}$ & $\begin{array}{l}0.038^{* * * *} \\
(0.001)\end{array}$ & $\begin{array}{l}0.053^{* * *} \\
(0.001)\end{array}$ \\
\hline Eta & $\begin{array}{l}0.933 * * * \\
(0.001)\end{array}$ & $\begin{array}{l}0.942 * * * \\
(0.001)\end{array}$ & $\begin{array}{l}0.929^{* * * *} \\
(0.001)\end{array}$ & $\begin{array}{l}0.942^{* * * *} \\
(0.001)\end{array}$ \\
\hline D-W (transformed) & 1.92 & 1.94 & 1.90 & 1.91 \\
\hline Adjusted $R^{2}$ & .82 & .82 & .71 & .71 \\
\hline$N$ & 1678 & 1637 & 1277 & 1236 \\
\hline
\end{tabular}

Dependent Variable: HR factor score. Endogenous variables: Income Inequality; Land Inequality. Instruments: agriculture's share in GDP, mineral exports, fuel exports; Catholic population; Iberian colonial heritage.

Unstandardized beta coefficients reported with robust standard errors in parentheses (adjusted for clustering by country). $* p<.10, * * p<.05, * * * p<.001$.

The results of the instrumented models are shown in Table 4. Regardless of the subset of countries considered, the coefficients for income inequality are still statistically significant and even slightly larger in their magnitude compared to the original (noninstrumented) models. As for the land inequality variable, the variable is still statistically significant but its effect appears substantially reduced. This might suggest that the effect of land maldistribution on rights abuse is not robust to the use of an alternative estimator. However, the results might also be due to the changes in the sample size across models. Indeed, in small samples the IV estimator can have a substantial bias (Wooldridge 2002, 465)-and/or to the choice of poor instruments, that is to say IVs that are in fact correlated with the error term.

In addition to addressing the endogeneity problem, we have also carried out further tests to explore two potential sources of specification error, respectively referring to the possibility that unobserved regional and international factors are the underlying correlates of personal integrity rights abuses. Perhaps the crossnational variation in inequality and rights violations are both independently caused by regional specificities such as political culture and historical legacies and/or international phenomena such as economic globalization. If this is the case, then the empirical relationship found in our models might actually be spurious. To control for regional-specific effects, we added six regional dummies to 
our models. ${ }^{27}$ With a few exceptions, these variables always reached levels of statistical significance, suggesting that regional specificities do take place in addition to the country-specific effects (already accounted for by the fixed-effects estimator). What is more interesting, however, is that both our explanatory variables maintain their statistical significance and do not show substantial variation in the magnitude of their effects.

To control for international factors, we re-ran our models by controlling for two alternative measures of economic globalization, including: trade dependency and foreign direct investments net inflows, both expressed as a percentage of GDP (World Bank Development Indicators WDI 2004). Across all model specifications, the estimates for our explanatory variables were almost identical (in a few cases, the beta coefficients changed only slightly and never substantially), while the effects of economic globalization were either insignificant (trade dependency) or inconsistent across the samples (foreign direct investments). Drawing on these findings, we can be more confident that the empirical relationships observed in our models were not affected by omitted variable bias due to the exclusion of regional specificities or globalization-induced effects.

\section{Discussion and Conclusion}

This article has sought to give greater attention to the idea of the distribution of resources and how it is related to the violation of civil and personal integrity rights. Such a distribution of resources was operationalized using measures of income and land inequality, both of which capture longer-term social processes of accumulation that we argued ought to be related to personal integrity rights violations. The results of our analysis suggest that findings for income inequality are stronger than those for land inequality. They also suggest that the descriptive account of the human rights situation in Brazil at the outset is one that can be generalized across the world. Brazil is in many ways a "typical" case that falls on the prediction line of our model estimation. It has had an historical record of maldistribution of income and land, and the persistence of personal integrity rights abuse, despite being a middle-income country. In addition to Brazil, Peru and Guatemala are other countries from the Latin American region that have high levels of income and land inequality and particularly troublesome records at personal integrity rights abuse. In sub-Saharan Africa, typical cases include Angola, Liberia, Sierra Leone, Somalia, Zambia, and Zimbabwe, while in South Asia and the Pacific, the typical cases are India, Pakistan, and the Philippines. In our sample of countries, these are all cases that fall more or less on the prediction line with above average scores for income inequality and below average scores for the protection of personal integrity rights.

But the direct relationship between the relative concentration of income and human rights violations illustrated through these cases and our more general analysis is clearly mediated by other factors, such as the level of democracy, economic development, as well as the level of domestic conflict and ethnic fractionalization. Democracy offers avenues for giving voice for those with grievances and for those who seek to challenge the concentration of resources in the ways that have been measured in this article. Moreover, the presence of multiple veto points (which is necessarily higher in those countries with higher levels of democracy) and stronger mechanisms for vertical and horizontal accountability have the most impact on decreasing human rights violations (see e.g., Bueno de

\footnotetext{
${ }^{27}$ We followed the World-Bank classification of world region and specified the following macro-regions: Sub-Saharian Africa; Asia, Eastern Europe; Latin America and Carribean; Middle East; Oceania; Western Europe and North America. One dummy variable was excluded to avoid collinearity.
} 
Mesquita et al. 2005a; Davenport 1999) even in the countries with less favorable distribution of resources.

But what are the pragmatic lessons to be learned from the analysis conducted here that may be of use to human rights practitioners interested in bringing about a more just world? The findings presented here provide new evidence that supports the general contention that different categories of human rights may well be inter-related. Broad patterns of concentration of resources (particularly income), which some would see as violating the notion of the "progressive realization" of economic and social rights, are related to patterns in the abuse of personal integrity rights. This article has shown that not only are high levels of national income related to the protection of personal integrity rights, but the distribution of that income, as well as a more equal access to crucial economic assets such as land, are also related to the protection of those rights. It thus builds on the earlier work by adding the social justice dimension and demonstrating its link to the protection of civil and personal integrity rights. Thus, efforts to promote economic growth and development should also place more emphasis on the quality of development to include the distribution of national wealth as it is accumulated. Though politically difficult and never without controversy, governments can address questions of income and land inequality through policies of agrarian reform and progressive taxation in ways that alleviate the worst forms of poverty and social exclusion. Indeed, our results demonstrate that politically inclusive institutions (in the form of democratic regimes) might not be sufficient to prevent rights abuses. Governments also need to pursue the realization of economically inclusive institutions, which spread the benefits of progress and development to all individuals in society.

One reading of the results suggests that democracy and or processes of democratization have tangible benefits that include a better protection of human rights, since democracies offer additional institutional mechanisms for citizens to channel their grievances in ways that can reduce their social and political precariousness captured in our measures of inequality and personal integrity rights protection. Another reading of these results, however, suggests that despite the positive relationship between democracy and the protection of personal integrity rights, the relationship between rights and inequality is upheld even after controlling for the level democracy. While international donor agencies and donor countries such as the World Bank, UNDP, DFID (UK), CIDA (Canada), SIDA (Sweden), and DANIDA (Denmark) have become more explicit since the 1990s about the connection between the quality of governance and its impact on developmental processes, it seems that in practical terms, income re-distribution and land reform ought to be coupled with the establishment and maintenance of democratic institutions that constrain the tendency to concentrate resources through mechanisms of vertical and horizontal accountability. In this way, resource redistribution and democracy building can be combined in ways that ought to have significant benefits in reducing the abuse of personal integrity rights.

While this study represents a preliminary effort at measuring and analyzing the impact of inequality on human rights protection, it clearly shows the importance of taking inequality into more serious consideration in cross-national studies of human rights violations. However, several aspects deserve further investigation. First, future studies would benefit from better data on distinct dimensions and types of inequality, both in terms of more precise estimations and temporal (as well as spatial) coverage. If so, it might be interesting to move beyond inequality between individuals and explore how "horizontal inequalities" (Stewart 2002) or systematic inequalities between culturally formed groups-such as ethnic, religious, and regionally defined groups-affect human rights protection. Furthermore, future research may need to move beyond aggregate 
national averages to measure phenomena (such as inequality), which might well show high degree of spatial heterogeneity, and instead consider sub-national unit of analysis. Our country case examples of Brazil, Peru, and Guatemala, for example, are all cases in which both inequality and the abuse of human rights show great spatial variation, where there are known regions within these countries with high levels of inequality and human rights abuse (e.g., the Northeast in Brazil and the highlands of Peru). Sub-national data on inequality could be coupled with equivalent sub-national measures of human rights violations in order to overcome the "whole-nation bias" and avoid the risk of miscoding cases and drawing insecure inferences. The need to move beyond national-level data and employ the sub-national method has been recently emphasized in different fields of comparative politics, such as democratization studies (Snyder 2001) and "contentious politics" (Tarrow 2007). ${ }^{28}$ Thus, in our view, future research ought to include disaggregated data on inequality, violence, and rights abuse in ways that reveal thus far "hidden" and unobserved forms of abuse that are in need of significant national, regional, and international attention.

\section{Appendix}

TABLE A1. Independent Variables Used in the Statistical Analysis (Summary Statistics with Between-unit and Within-unit Variation)

\begin{tabular}{|c|c|c|c|c|c|}
\hline Variable & Mean & St. Dv. & Min & $\operatorname{Max}$ & $N$ \\
\hline \multicolumn{6}{|c|}{ Income inequality } \\
\hline Overall & 43.48 & 7.16 & 20.07 & 64.75 & 3306 \\
\hline Between & & 7 & 20.76 & 58.13 & \\
\hline Within & & 2.09 & 31.98 & 61.81 & \\
\hline \multicolumn{6}{|c|}{ Land inequality } \\
\hline Overall & 52.92 & 20.99 & 2 & 100 & 3229 \\
\hline Between & & 20.14 & 4.12 & 92.44 & \\
\hline Within & & .57 & 9.62 & 83.86 & \\
\hline \multicolumn{6}{|c|}{ Level of democracy } \\
\hline Overall & .91 & 7.42 & -10 & 10 & 3541 \\
\hline Between & & 6.37 & -10 & 10 & \\
\hline Within & & 3.77 & -13.63 & 13.03 & \\
\hline \multicolumn{6}{|c|}{ Ethnic fragmentation } \\
\hline Overall & .46 & .26 & 0 & .93 & 3802 \\
\hline Between & & .26 & 0 & .93 & \\
\hline Within & & 0 & .46 & .46 & \\
\hline \multicolumn{6}{|c|}{ Ethnic fragmentation sq. } \\
\hline Overall & .28 & .24 & 0 & .87 & 3802 \\
\hline Between & & .24 & 0 & .87 & \\
\hline Within & & 0 & .28 & .28 & \\
\hline \multicolumn{6}{|c|}{ Domestic conflict } \\
\hline Overall & 3.41 & 2.83 & 0 & 12 & 2630 \\
\hline Between & & 2.16 & 0 & 9.16 & \\
\hline Within & & 1.80 & -2.29 & 10.08 & \\
\hline \multicolumn{6}{|c|}{ Population size } \\
\hline Overall & 15.93 & 1.54 & 12.30 & 20.98 & 4016 \\
\hline Between & & 1.54 & 12.47 & 20.86 & \\
\hline Within & & .16 & 13.52 & 16.68 & \\
\hline
\end{tabular}

\footnotetext{
28 Tarrow refers to the lack of statistical significance of land inequality found in several studies of civil war and points out that "land inequality ... in a region in which insurgency erupts may be washed out statistically if other regions in the country are relatively equal in landholdings. Only arduous and uncertain collection and analysis of subnational statistics ... make it possible to deal with the subnational sources of insurgency" (Tarrow 2007,589 our emphasis).
} 
Appendix: (Continued)

\begin{tabular}{lccccc}
\hline Variable & Mean & St. Dv. & Min & Max & $N$ \\
\hline Economic development & & & & & 3568 \\
$\quad$ Overall & 7.43 & 1.59 & 3.80 & 10.78 & 10.38 \\
Between & & 1.56 & 4.57 & 8.70 & \\
Within & & .22 & 5.16 & \\
\hline
\end{tabular}

\section{References}

Abouharb, Rod, and David L. Cingranelli. 2004. "Human Rights and Structural Adjustment: The Importance of Selection." In Understanding Human Rights Violations: New Systematic Studies, ed. Sabine C. Carey and Steven C. Poe. Aldershot: Ashgate.

Abouharb, Rod, and David L. Cingranelli. 2007. Human Rights and Structural Adjustment. Cambridge: Cambridge University Press.

Adriance, Madeleine C 1995. "The Brazilian Catholic Church and the Struggle for Land in the Amazon." Journal for the Scientific Study of Religion 34 (3): 377-382.

Alesina, Alberto, Arnaud Devleeschauwer, William Easterly, Sergio Kurlat, and Romain WACZiarg. 2003. "Fractionalization.” Journal of Economic Growth 8 (2): 155-194.

Amnesty International. May 2, 2007. "From Burning Buses to Caveirões: the Search for Human Security." Available at http://www.amnesty.org/en/library/info/AMR19/010/2007. (Accessed August 25, 2006.)

Arias, Desmond. 2006. “The Dynamics of Criminal Governance: Networks and Social Order in Rio De Janeiro." Journal of Latin American Studies 38 (2): 293-325.

Banks, A. S. 1994. Cross-Polity Time-Series Data Archive. Binghamton, NY: State University of New York.

Barratt, Bethany. 2004. "Aiding or Abetting: British Foreign Aid Decisions and Recipient Country Human Rights." In Understanding Human Rights Violations: New Systematic Studies, ed. Sabine C. Carey and Steven C. Poe. Aldershot: Ashgate.

Beck, Nathaniel, and Jonathan N. Katz. 1995. "What to Do (And Not to Do) with Time-Series Cross-Section Data." American Political Science Review 89 (3): 634-647.

Boix, Carles. 2003. Democracy and Redistribution. Cambridge: Cambridge University Press.

Boix, Carles, and Susan Stokes. 2003. "Endogenous Democratization." World Politics 55 (4): 517 549.

Bourguignon, François, And Christian Morrisson. 1998. “Inequality and Development: The Role of Dualism." Journal of Development Economics 57 (2): 233-257.

Boyle, Kevin. 1995. "Stock-taking on Human Rights: The World Conference on Human Rights, Vienna 1993.” Political Studies 43 (Special Issue): 79-95.

Branford, Susan, and Jan Rocha. 2002. Cutting the Wire: The Story of the Landless Movement in Brazil. London: Latin American Bureau.

Brockett, Charles D. 1992. "Measuring Political Violence and Land Inequality in Central America." The American Political Science Review 86 (1): 169-176.

Brohman, J 1996. Popular Development. Cambridge: Polity Press.

Bueno de Mesquita, Bruce, Feryal M. Cherif, George W. Downs, and Alastair Smith. 2005 a. “Thinking Inside the Box: A Closer Look at Democracy and Human Rights." International Studies Quarterly 49 (3): 439-480.

Bueno de Mesquita, Bruce, Alastair Smith, Randolph Siverson, and James D. Morrow. 2005 b. The Logic of Political Survival. Cambridge, MA: MIT Press.

Cingranelli, D. 1992. "Democracy and Human Rights in Less Developed Countries." Paper presented at the Annual Meeting of the American Political Science Association, Chicago.

Cingranelli, David, and David Richards. 1999. "Measuring the Level, Pattern, and Sequence of Government Respect for Physical Integrity Rights.” International Studies Quarterly 43 (2): 407418.

Claude, Richard P. 1976. “The Classical Model of Human Rights Development.” In Comparative Human Rights, ed. Richard P. Claude. Baltimore and London: Johns Hopkins University Press.

Collier, Paul, and Anke Hoeffler. 2004. "Greed and Grievance in Civil War." Oxford Economic Papers 56 (4): 563-595. 
Davenport, Christian. 1999. "Human Rights and the Democratic Proposition." Journal of Conflict Resolution 43 (1): 92-116.

Davenport, Christian, and David A. Armstrong. 2004. "Democracy and the Violation of Human Rights: A Statistical Exploration from 1976 to 1996." American Journal of Political Science 48 (3): 538-554.

Davidson, Russell, and James G. MacKinnon. 1993. Estimation and Inference in Econometrics. New York: Oxford University Press.

Deininger, KLAus, AND Lyn SQuire. 1996. “A New Data Set Measuring Income Inequality." World Bank Economic Review 10 (3): 565-591.

Domar, Evsey D. 1970. "The Causes of Slavery or Serfdom: A Hypothesis." The Journal of Economic History 30 (1): 18-32.

Duff, Ernest A., And John McCamant. 1976. Violence and Repression in Latin America: A Quantitative and Historical Analysis. New York: Free Press.

Engerman, Stanley L., And Kenneth L. Sokoloff. 1997. "Factor Endowments, Institutions, and Differential Paths of Growth Among New World Economies: A View from Economic Historians of the United States." In How Latin America Fell Behind, ed. Stephen Haber. Stanford, CA: Stanford University Press.

Engerman, Stanley L., And Kenneth L. Sokoloff. 2005. Colonialism, Inequality and Long-Run Paths of Development. NBER Working Paper 11057. Cambridge, MA.

Foweraker, Joe. 1981. The Struggle for Land: The Political Economy of the Pioneer Frontier in Brazil from 1930 to the Present. Cambridge: Cambridge University Press.

Frankema, Ewout. 2006. The Colonial Origins of Inequality: The Causes and Consequences of Land Distribution. Groningen: Groningen Growth and Development Centre, Faculty of Economics, University of Groningen.

Galbraith, James K., And Hyunsub Kum. 2004. "Estimating the Inequality of Household Incomes: A Statistical Approach to the Creation of a Dense and Consistent Global Data Set.' UTIP Working Paper N.22 (revised version). Available at http://utip.gov.utexas.edu/papers/utip_22rv5.pdf. (Accessed August 25, 2006.)

Gurr, Ted R. 1968. "A Causal Model of Civil Strife: A Comparative Analysis Using New Indices." American Political Science Review 62 (4): 1104-1124.

Gurr, Ted R. 1970. Why Men Rebel. Princeton, NJ: Princeton University Press.

Hafner-Burton, Emilie M., and Kiyoteru Tsutsui. 2005. "Human Rights in a Globalizing World: The Paradox of Empty Promises.” American Journal of Sociology 110 (5): 1373-1411.

Hathaway, Oona. 2002. "Do Treaties Make a Difference? Human Rights Treaties and the Problem of Compliance." Yale Law Journal 111 (8): 1932-2042.

Hausman, Jerry A. 1978. "Specification Tests in Econometrics.” Econometrica 46 (6): 1251-1271.

Heinisch, Reinhard. 1998. "The Economic Nature of Basic Human Rights: Economic Explanations of Cross-National Variations in Governmental Basic Human Rights Performance." Peace and Change 23 (3): 333-372.

Henderson, Chris. 1991. "Conditions Affecting the Use of Political Repression." Journal of Conflict Resolution 35 (1): 120-142.

Henderson, Chris. 1993. "Population Pressures and Political Repression.” Social Science Quarterly 74 (2): 322-333.

Hibbs, Douglas. 1973. Mass Political Violence: A Cross-National Causal Analysis. New York: Wiley.

Human Rights Watch. 2007. World Report 2007. New York: Human Rights Watch.

Jabine, Thomas B., And Richard P. Claude, eds. 1992. Human Rights and Statistics: Getting the Record Straight. Philadelphia: University of Pennsylvania Press.

Keith, Linda C. 1999. “The United Nations International Covenant on Civil and Political Rights: Does it Make a Difference in Human Rights Behaviour?”' Journal of Peace Research 36 (1): 95-118.

la Porta, Rafael, Florencio Lopez-de-Silanes, Andrei Shleifer, and Robert Vishny. 1999. “The Quality of Government." The Journal of Law, Economics, and Organization 15 (1): 222-279.

Lal, Deepak. 1998. Unintended Consequences: The Impact of Factor Endowments, Culture and Politics on Long-Run Economic Performance. Cambridge, MA: MIT Press.

Landman, Todd. 2002. "Comparative Politics and Human Rights." Human Rights Quarterly 24 (4): 890-923.

Landman, Todd. 2005a. "Review Article: The Political Science of Human Rights." British Journal of Political Science 35 (3): 549-572.

Landman, Todd. 2005b. Protecting Human Rights: A Comparative Study. Washington, DC: Georgetown University Press. 
Lichbach, Mark. 1987. "Deterrence or Escalation? The Puzzle of Aggregate Studies of Repression and Dissent." Journal of Conflict Resolution 31 (June): 266-297.

McCamant, John F. 1981. "Social Science and Human Rights." International Organization 35 (3): $531-552$.

Meyer, William H. 1996. "Human Rights and MNCs: Theory vs. Quantitative Evidence." Human Rights Quarterly 18 (2): 368-397.

Meyer, William H. 1998. Human Rights and International Political Economy in Third World Nations: Multinational Corporations, Foreign Aid, and Repression. Westport, CT: Praeger.

Meyer, William H. 1999a. "Confirming, Infirming, and Falsifying Theories of Human Rights: Reflections on Smith, Bolyard, and Ippolito Through the Lens of Lakatos." Human Rights Quarterly 21 (1): 220-228.

Meyer, William H. 1999b. "Human Rights and International Political Economy in Third World Nations: Multinational Corporations, Foreign Aid, and Repression." Human Rights Quarterly 21 (3): 824-830.

Midlarsky, Manus, ed. 1997. Inequality, Democracy, and Development, Cambridge: Cambridge University Press.

Midlarsky, Manus. 1999. The Evolution of Inequality: War, State Survival and Democracy in Comparative Perspective. Stanford: Stanford University Press.

Mitchell, Neil J. 2004. Agents of Atrocity: Leaders, Followers, and the Violation of Human Rights in Civil War. London: Palgrave.

Mitchell, Neil J., and James M. McCormick. 1988. "Economic and Political Explanations of Human Rights Violations." World Politics 40 (4): 476-498.

Moore, Will H. 2006. "Synthesis v. Purity and Large-N Studies: How Might We Assess the Gap between Promise and Performance?" Human Rights and Human Welfare 6: 89-97.

Most, Benjamin A., and Harvey Starr. 1989. Inquiry, Logic and International Politics. Columbia, SC: University of South Carolina Press.

Muller, Edward N. 1985. "Income Inequality, Regime Repressiveness, and Political Violence." American Sociological Review 50 (1): 47-61.

Muller, Edward N., ANd Mitchell A. Seligson. 1987. "Inequality and Insurgency." American Political Science Review 81 (2): 425-451.

Neumayer, Eric. 2005. "Do International Human Rights Treaties Improve Human Rights?” Journal of Conflict Resolution 49 (6): 925-953.

Plümper, Thomas, and Vera Troeger. 2007. "Efficient Estimation of Time Invariant and Rarely Changing Variables in Panel Data Analysis with Unit Effects." Political Analysis 15 (2): 124-139.

Plümper, Thomas, Vera Troeger, and Philip Manow. 2005. "Panel Data Analysis in Comparative Politics: Linking Method to Theory." European Journal of Political Research 44 (2): 327-354.

Poe, Steven. 2004. "The Decision to Repress: An Integrative Theoretical Approach to the Research on Human Rights and Repression." In Understanding Human Rights Violations: New Systematic Studies, ed. Sabine C. Carey and Steven C. Poe. Aldershot: Ashgate.

Poe, Steven, and Neal Tate. 1994. "Repression of Human Rights to Personal Integrity in the 1980s: A Global Analysis.”' American Political Science Review 88 (4): 853-872.

Poe, Steven, Neal Tate, and Linda C. Keith. 1999. "Repression of the Human Right to Personal Integrity Revisited: A Global Cross-National Study Covering the Years 1976-1993.' International Studies Quarterly 43 (2): 291-313.

Prosterman, Roy L., And Jeffrey M. Riedinger. 1987. Land Reform and Democratic Development. Baltimore, MD: John Hopkins University Press.

Rabushka, Alvin, and Kenneth A. Shepsle, eds. 1972. Politics in Plural Societies: A Theory of Democratic Instability. Columbus, OH: Merrill.

Russett, Bruce M., Howard R. Alker, Karl W. Deutsch, and Harold D. Lasswell. 1964. World Handbook of Political and Social Indicators. New Haven: Yale University Press.

SAnders, David. 1981. Patterns of Political Instability. London: Macmillan.

Seligson, Mitchell. 1997. "Tatu Vanhanen Thesis and the Prospects of Democracy in Latin America." In The Prospects of Democracy, ed. T. Vanhanen. London: Routledge.

Sigelman, Lee, and Miles Simpson. 1977. "A Cross-National Test of the Linkage between Economic Inequality and Political Violence." Journal of Conflict Resolution 21 (1): 105-128.

Singer, David, And Melvin Small. 1994. Correlates of War Project: International and Civil War Data 1816-1992. Ann Arbor, MI: InterUniversity Consortium for Political and Social Research.

Smith, Jackie, Melissa Bolyard, and Anna Ippolito. 1999. "Human Rights and the Global Economy: A Response to Meyer.” Human Rights Quarterly 21 (3): 207-219. 
SNyder, Richard. 2001. "Scaling Down: The Subnational Comparative Method." Studies in Comparative International Development 36 (1): 93-110.

Stewart, Frances. 2002. "Horizontal Inequalities: A Neglected Dimension of Development." Queen Elizabeth House Working Paper No. 81.

Stimson, James. 1985. "Regression in Space and Time: A Statistical Essay." American Political Science Review 29 (4): 914-947.

Tarrow, Sidney. 2007. "Inside Insurgencies: Politics and Violence in the Age of Civil War." Perspectives on Politics 5 (3): 587-600.

Taylor, Charles L., And David A. Jodice, eds. 1983. World Handbook of Political and Social Indicators: Political Protest and Government Change, Vol. II, 3rd edn. New Haven: Yale University Press.

United States Department of State. 2007. Country Practices on Human Rights: Brazil. Washington, DC: The United States Department of State. Available at http://www.state.gov/g/drl/rls/hrrpt/ 2006/78882.htm. (Accessed August 25, 2006.)

Van Oss, Adriann C. 2003. Church and Society in Spanish America. Amsterdam: Aksant.

Vanhanen, Tatu. 1984. The Emergence of Democracy: A Comparative Study of 119 States, 1850-1979. Helsinki: The Finnish Society of Science and Letters.

Vanhanen, Tatu. 1990. The Process of Democratization: A Comparative Study of 147 States, 1980-1988. New York: Crane Russak.

Vanhanen, Tatu. 1997. The Prospects of Democracy. London: Routledge.

Vanhanen, Tatu. 2003. Democratization: A Comparative Analysis of 170 Countries. London: Routledge.

Walker, Scott, and Steven Poe. 2002. "Does Cultural Diversity Affect Countries' Respect for Human Rights?" Human Rights Quarterly 24 (1): 237-263.

Wang, T.Y., William J. Dixon, Edward N. Muller, and Mitchell A. Seligson. 1993. "Inequality and Political Violence Revisited." American Political Science Review 87 (4): 979-993.

Weede, Erich. 1986. "Income Inequality and Political Violence Reconsidered." American Sociological Review 51 (3): 438-441.

White, Halbert. 1980. "A Heteroscedasticity-Consistent Covariance Matrix Estimator and a Direct Test for Heteroscedasticity." Econometrica 48 (4): 817-838.

Wooldridge, Jeffrey M. 2002. Econometric Analysis of Cross Section and Panel Data. Cambridge, MA: MIT Press.

Wooldridge, Jeffrey. 2003. Introductory Econometrics: A Modern Approach. Cincinnati, OH: SouthWestern College Publication.

Zanger, Sabine C. 2000a. "A Global Analysis of the Effect of Regime Changes on Life Integrity Violations, 1977-1993." Journal of Peace Research 37 (2): 213-233.

Zanger, Sabine C. 2000b. "Good Governance and European Aid: The Impact of Political Conditionality." European Union Politics 1 (3): 293-317. 